\title{
EVALUATION AND ANALYSIS OF BEARING CAPACITY OF BORED PILES AND DEEP-LAID PILE-BARRETTE FOR A HIGH-RISE BUILDING ON LOOSE GROUNDS BASED ON CALCULATIONS AND FIELD TESTS
}

\author{
Rashid. A. Mangushev ${ }^{1}$, Nadezda S. Nikitina ${ }^{2}$ \\ ${ }^{1}$ Saint-Petersburg State Architecture and Construction University, Saint-Petersburg, RUSSIA \\ ${ }^{2}$ National Research Moscow State University of Civil Engineering, Moscow, RUSSIA
}

\begin{abstract}
The study describes the standard procedure of the assessment of the bearing capacity of piles by field methods used in the Russian Federation. Basing on the example of an experimental deep-laid foundation pile (length $L=65 \mathrm{~m}$, diameter $D=1.2 \mathrm{~m}$ ) intended for a high-rise building designed for a thick layer of loose ground the study demonstrates the structure of a loading system on site and the results of static tests of piles in comparison with the results of analytical and numerical calculations. On the same construction site an experimental barrette-pile of rectangular cross-section measuring $3.3 \times 1.1$ with a length of $65 \mathrm{~m}$ was installed with the base in solid Proterozoic clays. The pile test was carried out using Osterberg cells. For this purpose in the process of the installation of the pile strain gauges were mounted in its reinforcing cage at 9 levels. The test barrette-pile was carried out in two stages. On the first stage a standard test of the whole pile in the top-down direction was performed (Top - Down). On the second stage, after reaching the maximum possible load, the "O - cell" element test was performed transmitting the load in two directions (up and down). "O - cell" was located at a depth of $50 \mathrm{~m}$ in the layer of bluestone. The article contains the graphs of the movements of pile from under the load applied on the first and second stages of the tests and the general assessment of the load-bearing capacity of the barrette-piles by different methods.
\end{abstract}

Keywords: experimental studies, piles-barrettes, bored piles, dependence of sediment-load, bearing capacity, test methods

\section{ОЦЕНКА И АНАЛИЗ НЕСУЩЕЙ СПОСОБНОСТИ БУРОНАБИВНЫХ СВАЙ И СВАЙ-БАРРЕТ ГЛУБОКОГО ЗАЛОЖЕНИЯ ДЛЯ ВЫСОТНОГО ЗДАНИЯ НА СЛАБЫХ ГРУНТАХ ПО РЕЗУЛЬТАТАМ РАСЧЕТОВ И ПОЛЕВЫХ ИСПЫТАНИЙ}

\author{
Р.А. Мангушев ${ }^{1}$, Н.С. Никитина ${ }^{2}$ \\ ${ }^{1}$ Санкт-Петербургский государственный архитектурно-строительный университет, \\ г. Санкт-Петербург, РОССИЯ \\ ${ }^{2}$ Национальный исследовательский Московский государственный строительный университет, \\ г. Москва, РОССИЯ
}

\begin{abstract}
Аннотация. Описана стандартная процедура оценки несущей способности свай полевыми методами, используемой в Российской Федерации. На примере изготовленной опытной сваи глубокого заложения (длина $L=65$ м, диаметр $D=1,2$ м) под высотное здание, спроектированное на большой толще слабых грунтов, показано устройство нагрузочной системы на строительной площадке и приведены результаты статического испытания сваи в сопоставлении с результатами аналитических и численных расчетов. На этой же строительной площадке выполнена опытная свая-баретта прямоугольного сечения размером 3,3 x 1,1 длиной 65 м с расположением основания в твердых протерозойских глинах. Испытание сваи проводилось с использованием ячеек Остерберга. Для этого, при устройстве сваи в ее арматурный каркас на 9 уровнях монтировались датчики деформации. Испытание опытной сваи-барреты проводилось в два этапа. На первом этапе выполнялось стандартное испытание всей сваи в направлении сверху-вниз (ТорDown). На втором этапе, после достижения максимально возможной нагрузки, выполнялись испытания
\end{abstract}


методом с помощью ячейки “О-cell” - элемента, передающего нагрузку в двух направлениях (вверх и вниз). Ячейка “О-cell” располагалась на глубине 50 м в толще твердых глин. В статье приведены графики перемещения сваи от приложенной нагрузки на первом и втором этапах испытаний и общая оценка несущей способности сваи-барреты по различным методам.

Ключевые слова: экспериментальные исследования, свай-баррет, буронабивные сваи, зависимость осадка-нагрузка, несущая способность, методики испытаний

\section{INTRODUCTION}

Evaluation of the bearing capacity of piles by analytical methods and further verification of these values by field tests is an important aspect of the design of pile foundations. There is a large number of analytical methods for calculation of load capacity of single piles which take into account the geometrical dimensions of the pile and characteristics of the surrounding soil [1]. However, very often the values obtained by calculation based on these methods significantly differ from the results of the field tests of the piles by vertical load method. First of all, it concerns large length piles designed in the ground with the protection of clay mortar or pipe casing. Generally, calculations results of the bearing capacity of piles made in accordance with the methodology based on Russian standards SNiP 24.13330.2011 [2] and SP 50-102-2003 [3] are significantly lower than the values of the carrying capacity obtained by standard vertical load capacity tests made in accordance with GOST 5686-2012 Soils. Methods of field tests by piles [4]. Field tests of barrette piles in Russia are still not standardized.

When preparing the design of the building of "Ohta-center" public and business complex with the height of $396 \mathrm{~m}$ two experimental cased bore piles with the diameter of $1.2 \mathrm{~m}$ and the length of $52.8 \mathrm{~m}$ as well as 5 experimental barrette-piles of $3,3 \times 1,0 \mathrm{~m}$ and with the length of $65 \mathrm{~m}$ were made and tested.

One of the tasks of the field tests was to determine the total bearing capacity of bore piles and barrette piles, as well as the bearing capacity calculated separately along the side surface and the base.

\section{ENGINEERING AND GEOLOGICAL CONDITIONS OF THE PILE TEST SITE}

Within drilling depth $(170 \mathrm{~m})$ the following deposits of subsoil were observed: man-triggered soils tg IV; lacustrine-marine deposits m, IIV; lacustrine-glacial deposits (upper sediments) of the Baltic Glacial Lake lg IIIb; lacustrine-glacial sediments of Luzhskaya glacial clay (bottom sediments) lgIIIz; glacial deposits of the Luzhskaya glacial clay gIIIlz; bed-rock disturbed and undisturbed clay Venda Vkt 2.

The averaged basic characteristics of soils are given in Table 1.

\section{EVALUATION OF THE BEARING CAPACITY OF THE EXPERIMENTAL PILE WITH DIAMETER $D=1.2 \mathrm{M}$ AND LENGTH $L=52.8 \mathrm{M}$}

In accordance with Russian standards [1, 2] analytical bearing capacity of hanging piles is determined by the formula

$$
F_{d}=\gamma_{c}\left[g_{c R} R A+u \Sigma \gamma_{c f} f_{i} h_{i}\right],
$$

where $\gamma_{c}$ is the coefficient of pile work conditions in the ground, for driven piles, $\gamma_{c}=1 ; R$ is the design resistance of the ground below the lower end of the pile; $A$ is the cross-sectional area of the pile, $\mathrm{m}^{2} ; u$ is the perimeter of the cross-section of the pile, $\mathrm{m}$; $f_{i}$ is the design resistance of the $i$-th soil layer along the lateral surface of the pile, $\mathrm{kPa} ; h_{i}$ is the thickness of the $i$-th layer of soil in contact with the side surface of the pile, m, etc. and Niemann $h_{i} \leq 2 \mathrm{~m}$; 
Evaluation and Analysis of Bearing Capacity of Bores Piles and Deep Laid Pile-Barrette for a High-Rise Building on Loose Grounds Based on Calculations and Field Tests

Table 1. The averaged basic characteristics of soils.

\begin{tabular}{|c|c|c|c|c|c|c|c|c|c|}
\hline No. & Ground name & icalindex & $\begin{array}{c}\gamma, \\
\mathrm{kN} / \mathrm{m}^{3} \\
\end{array}$ & $W$ & $e$ & $I_{L}$ & $\begin{array}{c}E, \\
\mathrm{MPa}\end{array}$ & $\begin{array}{c}\varphi, \\
\operatorname{deg}\end{array}$ & $\begin{array}{c}s, \\
\mathrm{MPa} \\
\end{array}$ \\
\hline 1 & Filled soil & $\operatorname{tg} I V$ & 17.5 & \multicolumn{6}{|l|}{-} \\
\hline 2 & $\begin{array}{l}\text { Marine and } \\
\text { lacustrine deposits }\end{array}$ & m, 1 IV & 19.6 & 0.256 & 0.683 & 0.71 & 14 & 24 & 0 \\
\hline 3 & $\begin{array}{l}\text { Upper lacustrine- } \\
\text { glacio sediments }\end{array}$ & $\lg$ III b & 18.6 & 0.360 & 0.980 & 1.1 & 4.5 & $7^{\text {th }}$ & 0.006 \\
\hline 4 & $\begin{array}{l}\text { Bottom lacustrine- } \\
\text { glacio sediments }\end{array}$ & Lg II Iz & 20.4 & 0.220 & 0.600 & 0.87 & 10.5 & $17^{\text {th }}$ & 0.030 \\
\hline 5 & $\begin{array}{l}\text { Glacial clay } \\
\text { deposits }\end{array}$ & G III lz & 21.5 & 0.160 & 0.43 & 0.25 & 17 th & 22 & 0.036 \\
\hline 6 & $\begin{array}{l}\text { Disturbed } \\
\text { Venda clay }\end{array}$ & Vkt2 & 21.4 & 0.176 & 0.503 & -0.35 & 16 & 14 & 0.130 \\
\hline 7 & $\begin{array}{l}\text { Undisturbed } \\
\text { Venda clay }\end{array}$ & Vkt2 & 22.3 & 0.129 & 0.367 & -0.79 & 113 & 22 & 0.840 \\
\hline
\end{tabular}

$g_{c R} ; g_{\text {with } f}$ is the coefficients of the working conditions of the ground under the bottom end and on a side surface of the pile, taking into account the effect of the pile manufacturing method.

The tests of piles with the diameter of $1.2 \mathrm{~m}$ and a length of $52.8 \mathrm{~m}$ with vertical static load were carried out using hydraulic jacks with the maximum load up to $3,500(35.000 \mathrm{kN})$ [Works on installation and testing of bored-injecting piles were conducted in 2009 by JSC Geoizol.]. For this purpose, a special loading platform was constructed from the cross beams, based on a system of 33 bored-injecting anchors of the Titan type (Fig. 1).

According to the Russian standards [4] the total bearing capacity of the pile is estimated by the value of load on the pile which results in its vertical deformation corresponding to value $\Delta=20$ $\mathrm{mm}$. In this case, it corresponded to a load value of $F_{d, s i t e}=25.000 \mathrm{kN}$.

Analytical calculations according to formula (1) showed the value of the total bearing capacity of this pile equaling to $F_{d \text {,calc }}=8320 \mathrm{kN}$. With that $71 \%(5.985 \mathrm{kN})$ corresponded to tip of the pile and only $29 \%(3.145 \mathrm{kN})$ to a side surface.

The value of the total load-bearing capacity calculated by $[2,3]$ turned out to be comparable with the results of calculations of this pile for vertical load ( $\mathrm{Fd}$, PLAXIS $11000 \mathrm{kN})$, performed under the PLAXIS 3D program.
The results of evaluation general bearing capacity of an experimental pile by various methods are listed in Table 2.

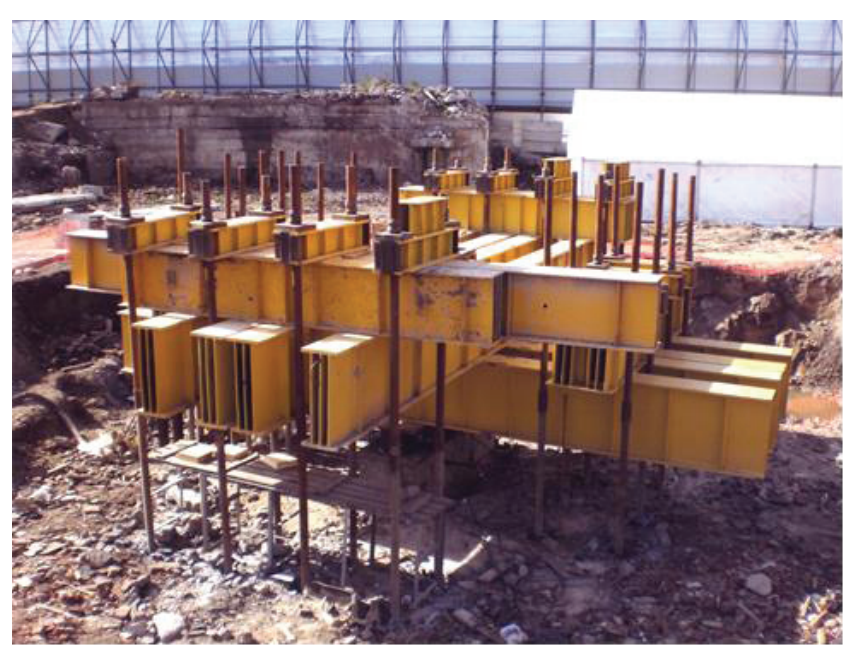

Figure 1. General view of the loading system for testing a pile with a static vertical load.

Table 2. The total load bearing capacity $F_{d}, k N$, of the pile $(D=1.2 \mathrm{~m}$ and $L=52.8 \mathrm{~m})$.

\begin{tabular}{|c|c|}
\hline $\begin{array}{c}\text { Calculation by the formula } \\
(1)[1,2], F_{d, \text { calc }}\end{array}$ & $8.320(-301 \%)$ \\
\hline $\begin{array}{c}\text { Calculation by PLAXIS } \\
\text { 3D, } F_{d, \text { PLAXIS }}\end{array}$ & $11,000(-227 \%)$ \\
\hline $\begin{array}{c}\text { The results of field tests, } \\
F_{d, \text { site }}\end{array}$ & 25,000 \\
\hline
\end{tabular}




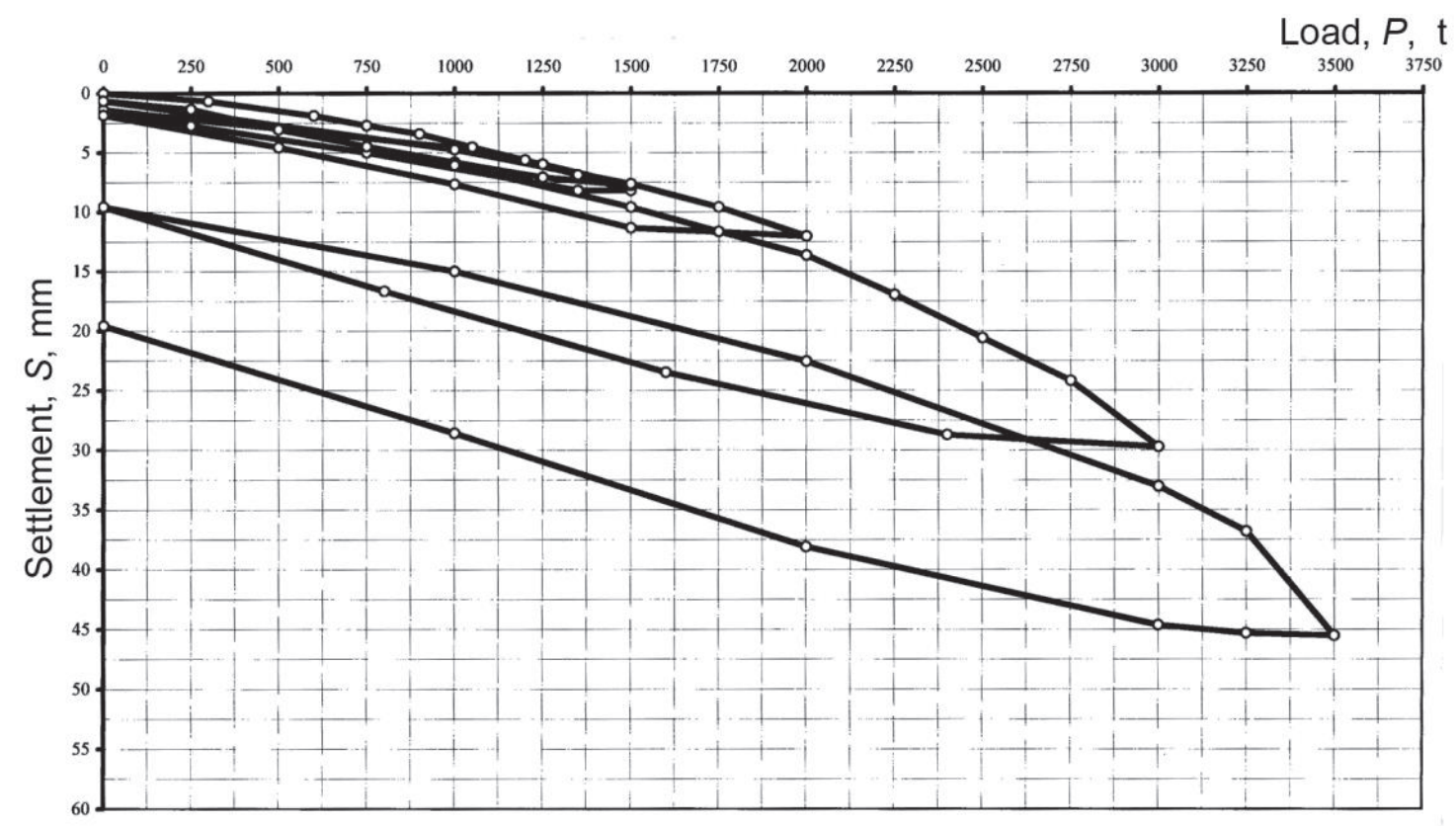

Figure 2. The results of the test of a pile with a diameter of $1.2 \mathrm{~m}$ and a length of $52.8 \mathrm{~m}$ with a vertical static load.

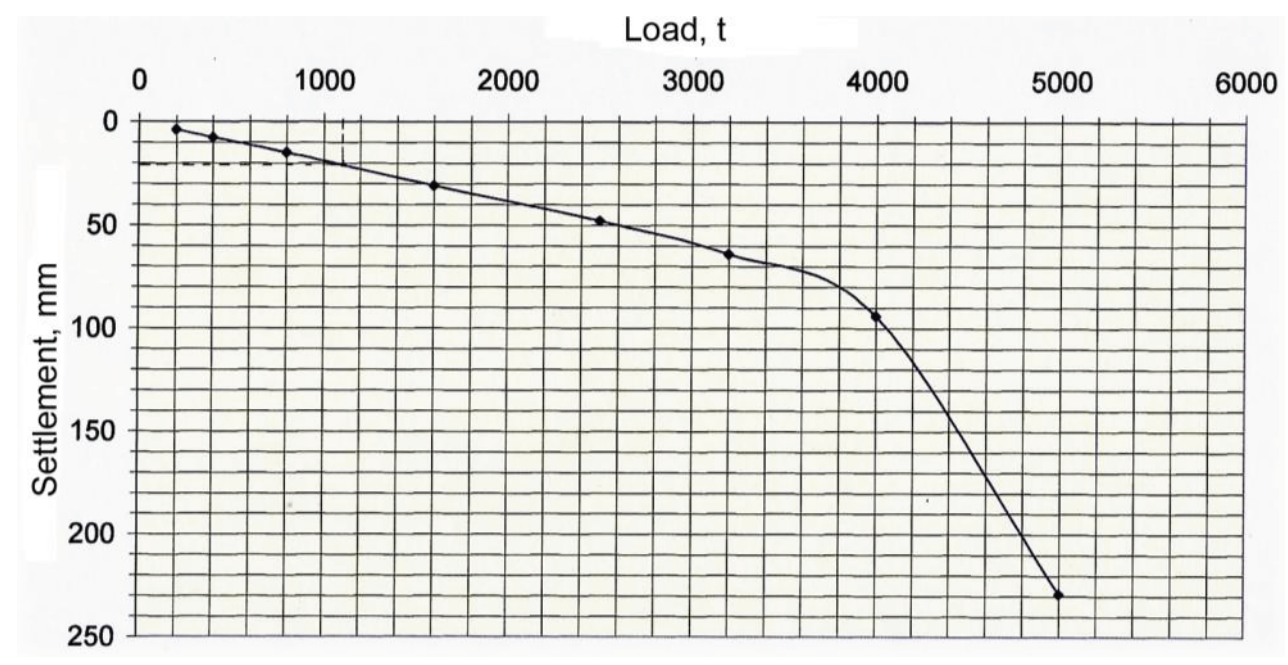

Figure 3. The results of calculations of the experimental pile by the vertical load, performed in PLAXIS D.

EVALUATION OF THE BEARING

CAPACITY OF THE

EXPERIMENTAL BARRETTE-PILE

WITH THE SIZE

\section{OF $L \times B=3.3 \times 1.0 \mathrm{M}$}

\section{AND LENGTH $L=65 \mathrm{M}$}

At the same construction site an experimental test of a pile of the size $l \times b=3.3 \times 1.0$ mand length $L=65 \mathrm{~m}$ with the location of the base in the thickness of the bedrock - Vendian clay Vkt 2 - took place. The tests were supposed to be carried out applying among other Osterberg cell "O - cell" and strain gauge, the scheme of disposition of which is shown in Fig. 4. The experimental barrette was tested by a vertical static load in two stages. The first stage involved a standard test by a vertical load applied to the head of the barrette-pile and directed down- 
Evaluation and Analysis of Bearing Capacity of Bores Piles and Deep Laid Pile-Barrette for a High-Rise Building on Loose Grounds Based on Calculations and Field Tests

wards (Top - down). After reaching maximal possible load, the second stage was carried out using "O - cell" at an altitude (-45.00). With this method the load was transmitted in two directions - up and down [5].

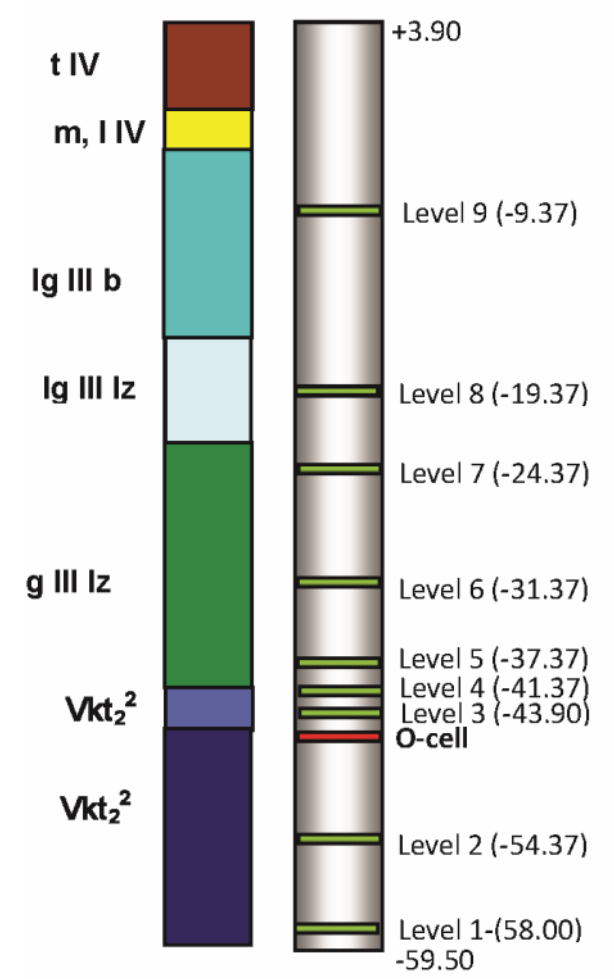

Figure 4. The layout of the " $\mathrm{O}$ - cell" and displacement sensors on an experimental barrette-pile

Fig. 5 shows the results of the tests of the experimental barrettes at the first stage of loading by the method (Top - down). With maximum load $35000 \mathrm{kN}$ the settlement was less than $20 \mathrm{~mm}$.

Extrapolation of the load-settlement graph to the horizontal line corresponding to $\Delta=20 \mathrm{~mm}$, made it possible to estimate the overall bearing capacity of the experimental barrette-pile at its primary load case at the value $F_{d, T o p}-$ Down $=$ $32.000 \mathrm{kN}$.

The analytical calculation of the experimental barrette-pile according to formula (1) $[2,3]$ showed the value of its total load-bearing capacity $F_{d, \text { calc }}=31.244 \mathrm{kN}$, which is very close to the results of the tests carried out using the Top - Down method.

The results of calculations according to the program PLAXIS 3D showed a total value of the bearing capacity of barrette $F_{d, P L A X I S}=27.800$
$\mathrm{kN}$ (Fig. 6), which is slightly less than the results obtained using Top - Down method.

The results obtained by the tests using Osterberg cell method "O - cell", carried out after the Top Down method test are presented in Fig. 7.

The blue line corresponds to the bottom-up test of the top part of the pile and allows to estimate the bearing capacity of the lateral surface of the barrette-pile. The red line corresponds to the Top-Down test and allows to estimate the bearing capacity of the heel of the barrette.

Extrapolation of the upper part of the graph 'loading' (blue line) to the intersection with the horizontal axis corresponding to the value $\Delta=$ $20 \mathrm{~mm}$ allows to estimate the bearing capacity of a lateral surface of a pile by the value of $F_{d, o-}^{f}$ cell $=29.500 \mathrm{kN}$. The lower part of the graph (red line) estimates the bearing capacity of the barrette tip with a value of at least $F_{d}{ }^{R}$,o-cell $=$ $13.000 \mathrm{kN}$. The total bearing capacity of the pile according to this test method was not less than $F_{\text {do-cell }}=42.500 \mathrm{kN}$.

As expected the total value of the bearing capacity of the barrette-pile by the repeated loading by the method of "O - cell" was higher than the value obtained by the primary loading by the Top - Down method (more than 30\%).

The summary table 3 shows test results of the tests using "O - cell" method and analytical calculations.

\section{CONCLUSION}

1) The results of the tests of the bearing capacity of experimental barrette piles of a diameter $D=$ $1.2 \mathrm{~m}$ and the length $L=52.8 \mathrm{~m}$ showed that observed values were significantly higher (over $200 \%$ ) than the results obtained by calculations according with the Russian standards [2,3], as well as by PLAXIS 3D program.

2) Results of the tests of the bearing capacity of the experimental barrette-pile of $3.3 \times 1.0 \mathrm{~m}$ and with a length $L=65 \mathrm{~m}$ were very close to the results of calculations according to Russian standards $[1,2](2.5 \%)$, and differed by $15 \%$ from the results obtained in PLAXIS 3D. 


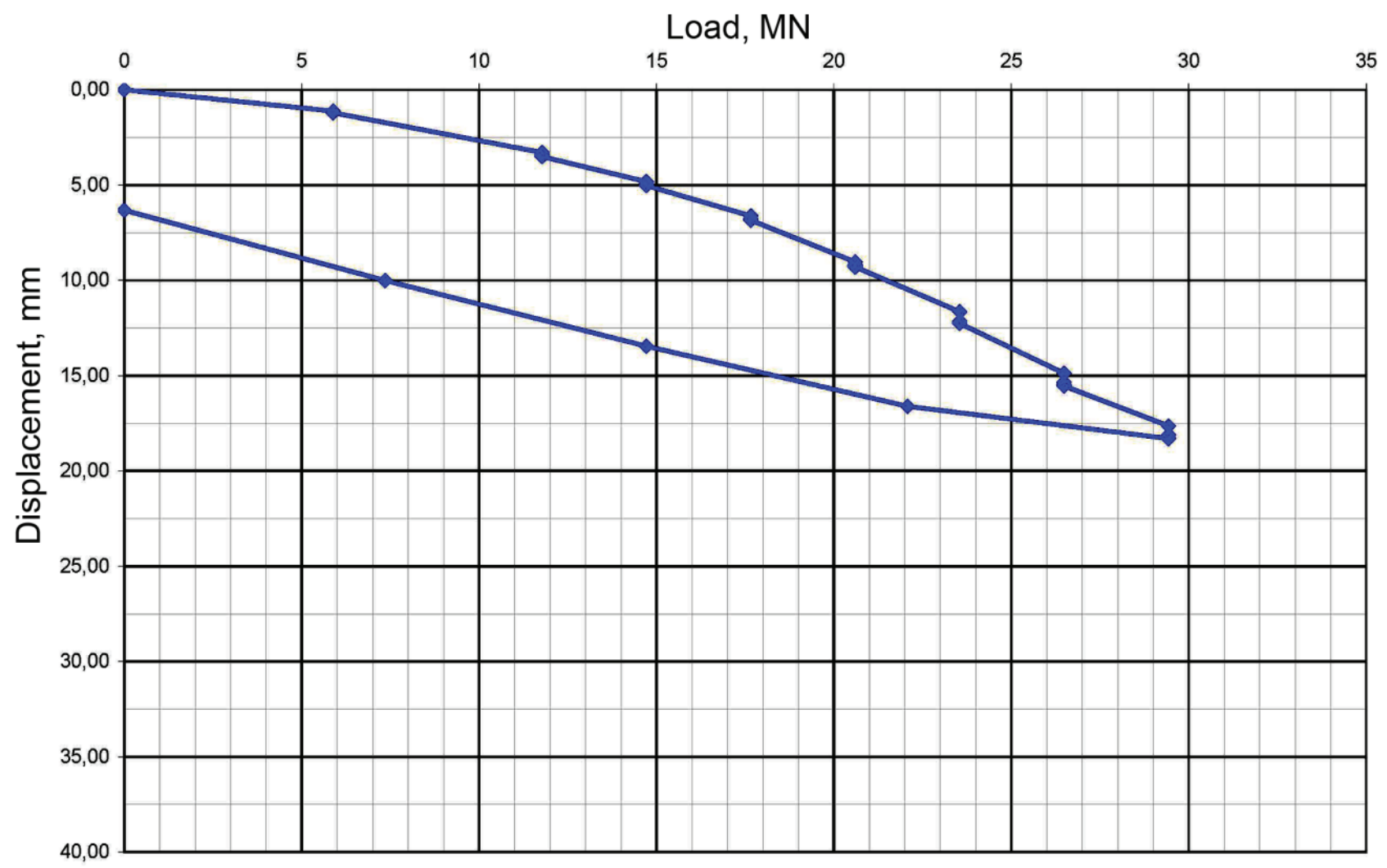

Figure 5. Graph of displacement the barrettes-pile resulted by the applied vertical load.

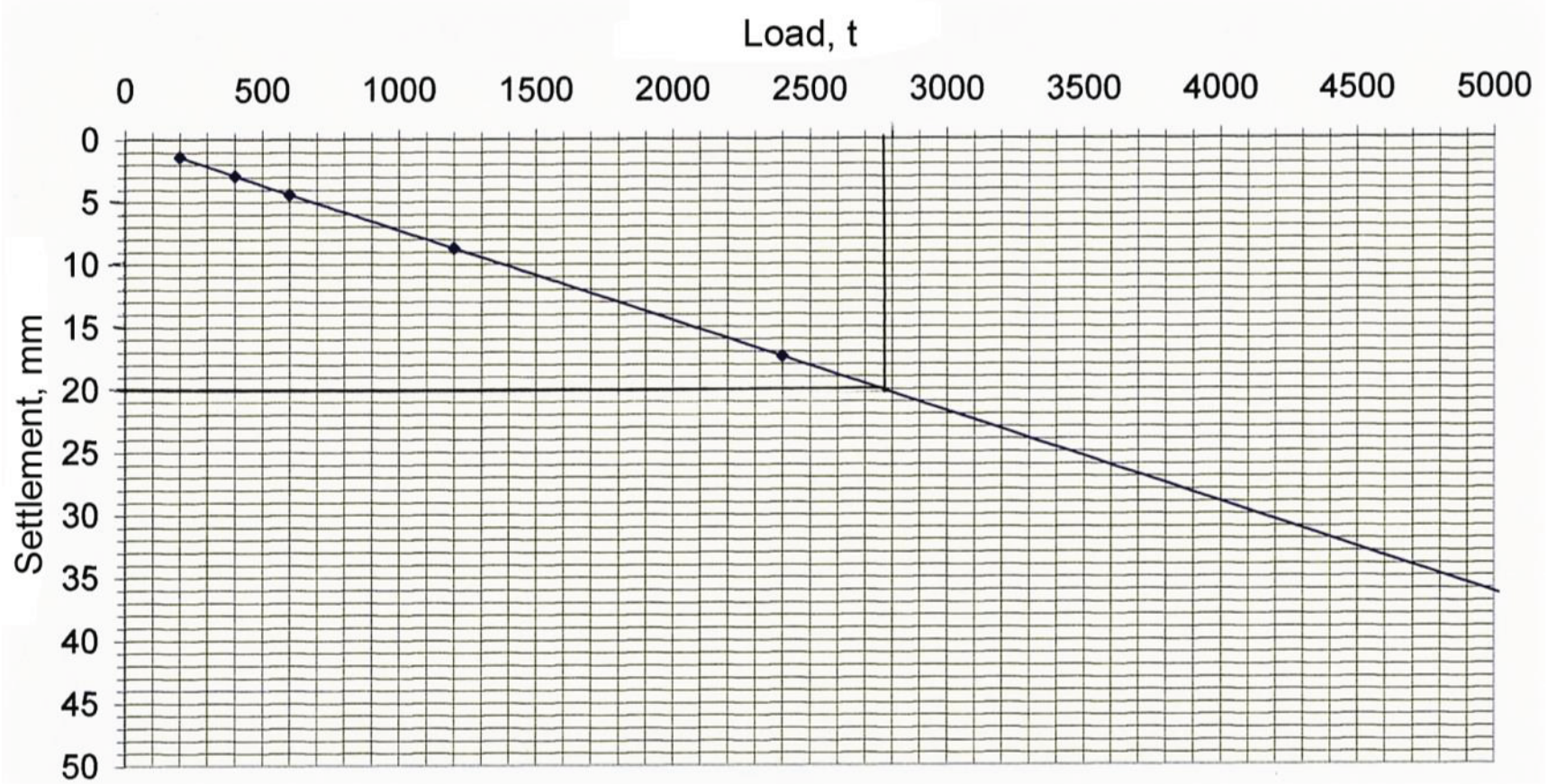

Figure 6. The results of the calculations of the experimental barrette-pile tests by vertical load (Top - down), formed in PLAXIS $3 D$ 
Evaluation and Analysis of Bearing Capacity of Bores Piles and Deep Laid Pile-Barrette for a High-Rise Building on Loose Grounds Based on Calculations and Field Tests

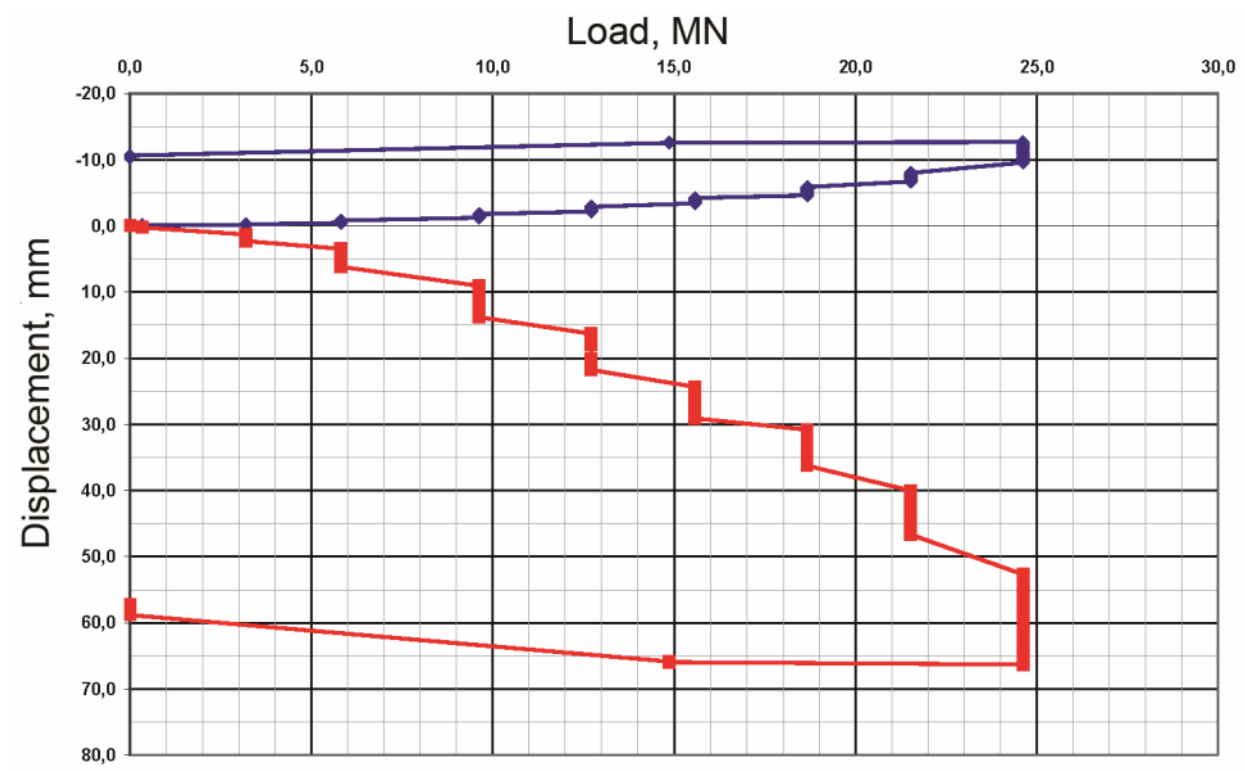

Figure 7. Graph of displacement of the pile from the applied vertical load By «O-cell» method.

Table 3. The total load bearing capacity $F_{d}, k N$, of the barrette-pile $3.3 \times 1.0 \mathrm{~m}$ and $L=65 \mathrm{~m}$ ).

\begin{tabular}{|c|c|}
\hline $\begin{array}{c}\text { Calculation by the } \\
\text { formula }(1)[1,2], F_{d, \text { calc }}\end{array}$ & $31244(-2.5 \%)$ \\
\hline $\begin{array}{c}\text { Calculation by PLAXIS } \\
\text { 3D, } F_{d, P L A X I S}\end{array}$ & $27800(-15 \%)$ \\
\hline $\begin{array}{c}\text { The results of Top - } \\
\text { Down field tests (primary } \\
\text { loading), } F_{d, \text { Top-Down }}\end{array}$ & 32000 \\
\hline $\begin{array}{c}\text { The results of «O - cell» } \\
\text { field tests (secondary }\end{array}$ & \\
loading): & \\
$F_{d, \text { o-cell }}$ & 42.500 \\
$F_{d,}^{f}$ o-cell & 29.500 \\
$F_{d, \text { o-cell }}$ & 13.000 \\
\hline
\end{tabular}

3) The bearing capacity of the ground by the tip $(13.000 \mathrm{kN})$ turned out to be twice lower than the bearing capacity of the lateral surface $(29.000 \mathrm{kN})$, despite the presence of a large thickness of weak soils alongside the barrettepile shaft.

\section{REFERENCES}

1. Mangushev R.A., Gotman A.L., Znamenskiy V.V., Ponomarev A.B. Svai i svaynyye fundayenty. Konstruk-tsii, proektirovanie i tekhnologii [Piles and Pile Foundations: Construction, Design and Technology]. Moscow: izd-vo ASV, 2015. 320 p. (rus)

2. SNiP 24.13330.2011. Svod pravil. Svaynye fundamenty. Aktualizirovannaya redaktsiya SNiP 2.02.03-85. Utv. Prikazom Minregiona RF ot 29.12.2011. № 635/2 [SP 24.13330.2011. Pile foundations. SNIP 2.02.03-85 updated edition] (rus)

3. SP 50-102-2003. Proektirovanie i ustroystvo svaynykh fundamentov. [SP 50102-2003. Design and installation of pile foundations]. Moscow: Stroyizdat, 2004. 81 p. (rus).

4. GOST 5686-2012. Grunty. Metody polevykh ispytaniy svayami. [GOST 56862012. Soils. Methods of field testing of piles]. Moscow: 2013. (rus)

5. Kolodiy Ye.V. Sravnitelnyy analiz sovremennykh metodov otsenki nesushchey sposobnosti svay (na primere svai-baretty $\mathrm{V}$ inzhenerno-geologicheskikh usloviyakh Sankt-Peterburga) [Comparative analysis of 
modern methods of assessing the loadcarrying capacity of piles (on the example of a pile-barrette in the engineering and geological conditions of St. Petersburg] // Sbornik trudov nauchno-tekhnicheskoy konferentsii «Aktualnye voprosy geotekhniki pri reshenii slozhnykh zadach novogo stroitelstva i rekonstruktsii [Topical issues of geotechnics at the solution of complex challenges of new construction and reconstruction: collection of works of scientific and technical conference], SPbGASU, Saint-Petersburg: 2010. Pp. 8795. (rus)

\section{СПИСОК ЛИТЕРАТУРЫ}

1. Мангушев Р.А., Готман А.Л., Знаменский В.В., Пономарев А.Б. Сваи и свайные фундаменты. Конструкции, проектирование и технологии / Под. ред.чл.-корр. РААСН, д.т.н., проф. Мангушева Р.А. М.: Изд-во АСВ, 2015. 320 с.

2. СНиП 24.13330.2011. Свод правил. Свайные фундаменты. Актуализированная редакция СНиП 2.02.03-85. Утв. Приказом Минрегиона РФ от 29.12.2011. № $635 / 2$.

3. СП 50-102-2003. Проектирование и устройство свайных фундаментов. М.: Стройиздат, 2004. $81 \mathrm{c.}$

4. ГОСТ 5686-2012. Грунты. Методы полевых испытаний сваями. М., 2013.

5. Колодий Е.В. Сравнительный анализ современных методов оценки несущей способности свай (на примере сваи-баретты в инженерно-геологических условиях Санкт-Петербурга) // Сборник трудов научно-технической конференции «Актуальные вопросы геотехники при решении сложных задач нового строительства и реконструкции», СПбГАСУ, СПб, 2010. C. 87-95.

Mangushev Rashid Abdullovich, Corresponding Member of the Russian Academy of Architecture and Con-struction
Sciences, Professor, Doctor of Technical Sci-ences; Head of Geotechnical Department, Saint-Petersburg State Architecture and Construction Universi-ty, Director of Scientific and Consulting Centre of Ge-otechnologies, Russia, SaintPetersburg, 2-ya Krasnoarmeyskaya 4; e-mail: ramangushev@yandex.ru.

Nadezda Sergeevna. Nikitina, PhD, Professor, Department of "Soil Mechanics and Geotechnical", Moscow State University of Civil Engineering (National Research University), 26, Yaro-slavskoe Shosse, Moscow, 129337, Russia; phone/fax: +7(495) 287-49-14; e-mail: nsnikitina@mail.ru.

Мангушев Рашид Абдуллович, член-корреспондент PAАCH, профессор, доктор технических наук; заведующий кафедрой геотехники Санкт-Петербургского государственного архитектурно-строительного университета (СПбГАСУ), директор научно производственного консалтингового центра геотехнологий СПбГАСУ. Россия, Санкт-Петербург, 2-я Красноармейская 4; e-mail: ramangushev@yandex.ru.

Никитина Надежда Сергеевна, профессор кафедры «Механики грунтов и геотехники» Московский государственный строительный университет, г. Москва, Россия, 129337, Ярославское шоссе, д.26,тел./факс: +7(495) 287-49-14; e-mail: nsnikitina@mail.ru. 